\title{
THE EPISTOLARY HISTORY
}

\author{
Time for a change.
}

\section{BY ALEX SHVARTSMAN}

1: $1 / 9 / 12$
Hey Cat,
We finally did it! The time machine works.
The blokes are talking about trying to sell

The blokes are talking about trying to sell it to some big technology company, but I have a better idea.

A quick and easy trip to grandgrand-grandpa Oskar's machine shop in 1890 Weimar, a couple of sketches and a sample left on his desk, and presto: Oskar invents duct tape and builds a fortune in Germany; enough of it gets passed on to my branch of the family a century later that we don't need any vulture capitalists grabbing the lion's share of the time-travel tech profits. Besides, with a little one on the way we can use the extra dough.

So I'm e-mailing to let you know that I'm staying at Oxford to work on this tonight and might miss dinner. On the bright side, if things work out how I expect them to, we'll be dining on caviar instead of pizza.

2: September 01, 2012

My Dear Cathy,

Yesterday was the happiest day of my life. I finally perfected my invention, but the news of your pregnancy is a miracle that outshines any achievements of mere science.

I couldn't sleep last night, thinking of the world our son or daughter will be born into. England ravaged by 70 years of total war and the constant Nazi air raids - it's not the sort of place in which I want them to spend their childhood.

With a working prototype of the time machine in hand, I have both the means and the moral responsibility to fix the mistakes of the past. I'm going to travel back to 1930 and kill Hitler.

If all goes well, you'll wake up and read this note in a far better world.

\section{3: Сентябрь 01, 2012}

Dear Katya,

My comrades at the Oxford Universitet and I have finally perfected the device. We're

$\rightarrow$ NATURE.COM

Follow Futures:

@ @NatureFutures

f go.nature.com/mtoodm scheduled to present Project 'Machina Vremeny' to the Politburo in the morning.

When you shared the great news last night, I couldn't sleep, thinking of the world our children will be born into. I can't stand the thought of them living in the constant fear of nuclear annihilation that is hanging over all the free people of Socialist Europe.

surely delayed technological process. By God, we don't even yet have the steam-powered flying carriage, the invention of which the fictioneers of old predicted to occur back in the 1970s.

The world would have been a better place had the civilized man never ventured into the Americas, and thence I shall presently activate the Chronomat and use it to prevent Mr Columbus from undertaking his journey.

By the time this letter reaches you at the clinic, we shall all be living in a better tomorrow.

\section{4: Haab: 12 Mol. Tzolkin: 10 Muluc Dear Diary,}

Once again, I failed to meet a suitable partner today.

I dragged myself to the drinking hall, but there were few single women there, and none of them interested in my advances. Instead, I found myself drinking alone and listening to a pair of inebriated Maya who were apparently anxious about an impending end of the world.

Their main argument seemed to be that the ancient Christian calendar extended no farther than 2012. As if the priests of an extinct Eurasian cult possessed the scientific knowledge to

I possess the means and the moral authority to prevent 70 years of the cold war. I'm going to travel back to 1930 and kill Roosevelt.

If all goes well, you'll wake up and read this note in the better world, one where communism has already been achieved.

7. First day of September in the year of our Lord two thousand and twelve

Dearest Catherine,

I received your kind letter a few days since and am dreadfully sorry that the fertility infusions are not yet working. I direct this letter to you in hope that my own fortuitous developments shall cheer your heart and improve your disposition.

The Chronomat device I've endeavoured to design is finally complete. My lifelong dream of single-handedly defending Her Majesty's Empire against those belligerent ruffians from the American colonies is within my grasp. Two centuries of combating the rebels have sapped our resources and predict some future catastrophe. Absurd! I went home, alone. I couldn't sleep, lying in bed and imagining what it might be like to invent the means of changing the past. How different would our world be if the Mayan explorers had never arrived at the shores of Europe all those centuries ago? What sort of culture and science could the pale-faced tribes of this continent have developed if they weren't wiped out or subjugated by the superior Western civilization?

We'll never know. Travelling back in time is a silly fantasy I conceived of only due to imbibing too much balché yesterday evening.

I shall purge such thoughts from my mind, bathe, rest and prepare myself. Tomorrow, I shall go out and try again. Somewhere out there is a woman who is destined to be my soul mate. I haven't met her yet, but I remain an optimist.

Alex Shvartsman is a writer and game designer from Brooklyn, New York. His other fiction is linked at www.alexshvartsman.com. 